原著

透析会誌 $27(5) ： 349 \sim 354,1994$

\title{
透析アミロイドーシスによる頸部脊髄症，腰部脊柱管狭窄症例の検討 一後縦靫帯・黄色靫帯肥厚例を中心に一
}

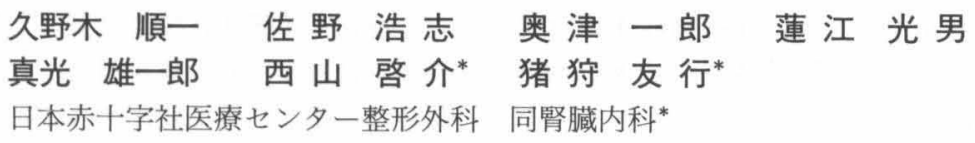

key words : 透析アミロイドーシス, 頸部脊髄症, 腰部脊柱管狭窄症, 後縦靱帯肥厚, 黄色靱帯肥厚

〈要旨〉

血液透析患者の脊椎合併症に対し手術療法を施行した 14 例 (頸椎 7 例, 腰椎 7 例) のうち, 圧迫性脊髄症または馬 尾·神経根症の原因が, 主として资柱管内靶帯および硬膜外腔のアミロイド沈着によると診断された 6 例（頸椎 4 例, 腰椎 2 例）について検討した. 年齢は 51 歳から 68 歳（平均 58.5 歳）で, 透析歴は 15 年から 20 年 (平均 17.4 年) と長期化していた. 頸部脊髄症を呈した 4 例では, MRI とCT ミエログラムにて, 頸椎後縦鞋帯肥厚と黄色靭帯肥厚 が認められた。 いずれも冷柱管拡大術により, 神経症状の改善を得た。手術所見では, 黄色靶帯肥厚と硬膜外腔のア ミロイド沈着を認め，硬膜管は黄色靫帯と癒着していた．組織学的には黄色靭帯内に congo red 染色と抗 $\beta_{2}$-microgIobulin 陽性の多量のアミロイド沈着が証明された。

腰部脊柱管狭窄を呈した 2 例でも，アミロイド沈着による黄色靸帯の著明な肥厚により硬膜管が絞扼されており， 椎弓切除と黄色靫帯の切除により軽快した.

長期透析例では, アミロイド沈着による後縦靶帯・黄色靭帯肥厚が頸部脊髄症や腰部脊柱管狭窄症の原因として重 要である. 本疾患では単純X 線所見は通常正常であり, 破壊性脊椎関節症とは異なった疾患群として注目すべきであ る.

\section{Clinical studies of cervical myelopathy and lumbar spinal canal stenosis due to dialysis-associated amyloidosis}

Junichi Kunogi, Hiroshi Sano, Ichiro Okutsu, Mitsuo Hasue, Yuichiro Sanemitsu, Keisuke Nishiyama*, Tomoyuki Ikari*

Department of Orthopedic Surgery, and Nephrology*, Japanese Red Cross Medical Center

We performed spinal decompressive surgery in 14 hemodialysis patients, 7 with cervical myelopathy and 7 with lumbar radiculopathy. In four of the cases of cervical myelopathy the spinal cord was compressed by the deposition of amyloid in the hypertrophied posterior longitudinal and/or ligamentum flavum and epidural space. In two of the cases of lumbar canal stenosis the dural tube was compressed by the hypertrophied ligamentum flavum. The age range in these 6 cases was 51 to 68 years (average: 58.5 ) and the duration of hemodialysis ranged from 15 years to 20 years (average : 17.4). The hypertrophy of the posterior longitudinal ligament and the ligamenta flava was diagnosed preoperatively by MRI and CT-myelogram.

Surgery revealed hypertrophied ligamenta flava and adhesion of the dural tube to the spinal canal. Histopath ological examination of the surgical specimens showed massive deposition of amyloid, which was histochemically identified as $\beta_{2}$-microglobulin.

We consider hypertrophy of the posterior longitudinal ligament and ligamenta flava mainly due to amyloid deposition to be one of the major factors causing cervical myelopathy and lumbar spinal canal stenosis in longterm hemodialysis patients.

久野木順一 日本赤十字社医療センター整形外科％ 150 渋谷区広尾 4-1-22 (03-3400-1311)

〔受付: 平成 5 年 11 月 4 日, 受理 : 平成 6 年 1 月 25 日〕 


\section{はじめに}

血液透析の長期化と透析患者の高齢化に伴い，透析ア ミロイドーシスに伴う関節疾患とともに，脊椎合併症の 増加が問題となりつつある. 従来, 透析に直接関連ある 脊椎合併症として破壊性脊椎関節症 (DSA) がよく知ら れているが, これとは異なり透析アミロイドーシスに伴 い脊柱管内靶帯の肥厚を生じ, 圧迫性脊髄症または馬 尾・神経根症をきたす新しい病態を経験したため, 診断 と治療について報告する.

\section{対象および方法}

血液透析患者の脊椎合併症に対し手術療法を施行した 14 例（脊椎手術群：頸椎 7 例, 腰椎 7 例）を, 対象とし た。年齢は 32 歳から 68 歳 (平均 51.2 歳), 男性 9 例, 女性 5 例であった. 14 例の透析期間は 4 年から 20 年(平 均 15.4 年) であった。このうち圧迫性脊髄症または馬 尾・神経根症の原因が主としてアミロイド沈着による脊 柱管内勒帯の肥厚および硬膜外腔のアミロイド沈着によ るものは頸椎 4 例, 腰椎 2 例であった. 6 例の年齢は 51 歳から 68 歳 (平均 58.5 歳), 女性 1 例, 男性 5 例で透析 歴は 15 年から 20 年 (平均 17.4 年) と全例が長期透析例 であった。

これらの症例に対し, 臨床所見, 画像診断所見, 手術 所見，病理組織所見について調べた。

\section{結果}

1. 脊椎手術を要した透析例の内訳（表）

脊椎合併症の原因疾患名は表のごとくで, 透析患者に 特有な脊椎合併症と考えられたものは 8 例あった。頸椎 後縦勒帯, 黄色勒帯肥厚と硬膜外腔のアミロイド沈着に よる脊髄症が 4 例, DSA に伴うすべり症が 2 例, 黄色靶 帯肥厚による腰部脊柱管狭窄が 2 例であった。春椎変性 疾患を合併したものは 6 例で, 頸椎椎間板ヘルニア, 頸 椎症性脊髄症, 腰椎変性すべり症, 椎間板ヘルニア, 硬 膜外囊腫, 外側型狭窄が各々 1 例であった. DSA が, 臨 床症状発現の原因となっていたのは，頸椎にすべりを生 じ，頸髄症を発症した 1 例と，腰椎すべり症を合併した 1 例のみであり, DSA のみで重篤な脊椎合併症を生じる 例は比較的少ないと考えられた。

2 . 後縦勒帯・黄色勒帯肥厚例の臨床的特徵

頸部脊髄症の 4 例では, 脊椎合併症の他にも, 手根管 症候群，多関節にわたるアミロイド関節症，弾発指によ る手指の屈曲拘縮などを高率に合併するため, 脊髄症の 臨床所見がマスクされ，診断の遅れた症例が存在した。

さらに画像診断上，軽度の DSA 所見を伴った頸椎後 縦勒帯肥厚例の 1 例を除き, 単純X線所見は正常であっ た。診断は MRI または脊髄造影と CT ミエログラ フィーにて, 脊髄または硬膜管の圧迫とともに，後綐靯

表 脊椎手術を行った透析症例

\begin{tabular}{|c|c|c|c|c|c|c|}
\hline 症例 & 年齢・性 & 透析期間 & 罹患部位 & 病名 & 術式 & 成績 \\
\hline $1^{*}$ & 61 男 & 15 年 & 頸椎 & $\begin{array}{l}\text { 後縦勒帯・黄色靱帯肥厚, 硬膜外腔 } \\
\text { アミロイド沈着 }\end{array}$ & 椎弓拡大術 & 可 \\
\hline $2^{*}$ & 68 男 & 15 & 頸椎 & $\begin{array}{l}\text { 後縦䩡帯・黄色靱帯肥厚, 硬膜外腔 } \\
\text { アミロイド沈着 }\end{array}$ & 椎弓拡大術 & 優 \\
\hline $3^{*}$ & 64 女 & 18 & 頸椎 & $\begin{array}{l}\text { 後縦靱帯・黄色靱帯肥厚, 硬膜外腔 } \\
\text { アミロイド沈着 }\end{array}$ & 椎弓拡大術 & $\begin{aligned} & \text { 良 } \\
& \rightarrow \text { 死亡 }\end{aligned}$ \\
\hline $4^{*}$ & 51 男 & 20 & 頸椎 & $\begin{array}{l}\text { 後縦靱帯・黄色靯帯肥厚, 硬膜外腔 } \\
\text { アミロイド沈着 }\end{array}$ & 椎弓拡大術 & 優 \\
\hline $5^{*}$ & 53 男 & 18 & 頸椎 & 破壊性春椎関節症・すべり症 & $\begin{array}{l}\text { 前方固定後 } \\
\text { インスツルメン } \\
\text { テーション } \\
\text { 前方固定術 }\end{array}$ & 良 \\
\hline 6 & 55 女 & 17 & 頸椎 & 椎間板ヘルニア & $\begin{array}{l}\text { インスツルメン } \\
\text { テーション }\end{array}$ & 良 \\
\hline 7 & 44 女 & 12 & 頸椎 & 頸椎症性脊髄症 & 椎弓拡大術 & 良 \\
\hline $8^{*}$ & 54 男 & 17 & 腰椎 & 黄色靶帯肥厚 - 春柱管狭窄症 & 椎弓切除術 & 優 \\
\hline $9^{*}$ & 52 男 & 19 & 腰椎 & 黄色靶帯肥厚 - 榛柱管狭窄症 & $\begin{array}{l}\text { 椎弓切除術 } \\
\text { 椎弓切除術 }\end{array}$ & 優 \\
\hline 10 & 50 女 & 19 & 腰椎 & 変性すべり症 & $\begin{array}{l}\text { インスツルメン } \\
\text { テーション }\end{array}$ & 優 \\
\hline 11 & 47 男 & 4 & 腰椎 & 椎間板ヘルニア & 経皮的髄核摘出術 & 優 \\
\hline 12 & 44 男 & 15 & 腰椎 & 硬膜外囊腫 & 囊腫切除 & 優 \\
\hline 13 & 32 女 & 17 & 腰椎 & 外側型狭窄症 & 椎弓部分切除術 & 良 \\
\hline $14^{*}$ & 62 男 & 12 & 腰椎 & 破壊性脊椎関節症・すべり症 & 椎弓切除術 & 優 \\
\hline
\end{tabular}

* 透析患者に特有な脊椎疾患例 
帯や黄色勒帯の肥厚を確認することによりなされた。

3 . 手術術式と術中所見, 手術成績

全脊椎手術例 14 例中, 頸椎の DSA と頸椎椎間板へル ニアの 2 例に頸椎前方固定術を行い, 他の例では後方除 圧を行った。

頸椎後縦勒帯・黄色靯帯肥厚例に対しては, 全例で脊 柱管拡大術をハイドロキシアパタイトの棘突起スペー サーを使用して行った。

黄色勒带肥厚による腰部脊柱管狭窄の 2 例では, 椎弓 切除と肥厚した黄色勒帯の切除を行った。

術中所見では頸椎後縦靯帯肥厚の 4 例ではいずれも硬 膜管周囲にアミロイド沈着を認め, 硬膜管と肥厚した黄 色勒帯は高度に癒着していた。腰椎黄色勒帯肥厚の 2 例 では, $L 4 / 5$ 間の黄色勒帯肥厚が主病変となっており, 最 大の厚さは各々 $13 \mathrm{~mm}, 11 \mathrm{~mm}$ と著明に肥厚していた。

全手術例 14 例の術後 1 年以内の短期成績は, 優 9 例, 良 5 例で可・不可の症例はなかった。脊椎勒帯肥厚例 6 例では, 優 4 例, 良 2 例であった。

術中, 術後の合併症としては頸椎後縌䩲帯肥厚の 1 例 で, 術中低血圧が原因と考えられるシャントの閉塞を生 じた.また他の頸椎後縦靯帯肥厚の 1 例は, 術後, 症状 の改善を見たが, 4 か月後に脳血管障害により死亡した。

4.病理組織所見

黄色靯帯と椎間板では, 肉眼的な勒帯組織の肥厚の有 無にかかわらず, 全例に congo red 染色と抗 $\beta_{2}$-microglobulin 抗体を用いた免疫組織染色陽性のアミロイドが 証明された. 特に頸椎後縦靯帯肥厚の 4 例と腰部脊柱管 狭窄の 2 例では黄色勒帯内に多量のアミロイド沈着が認 められた。また多核巨細胞を含む炎症細胞浸潤と線維性 結合織の増殖がみられた。

症例

症例：頸椎後縦靯帯・黄色靱帯肥厚, 硬膜外腔アミロ イド沈着, 68 歳, 男性.

主訴：歩行障害, 上肢筋力低下.

既往歴：慢性腎炎により，1977 年より 15 年間血液透 析を受けている. 手根管開放術の既往がある.

現病歴：1991 年 1 月より右手のしびれが出現. 同年 9 月より, 痙性四肢麻痺が急速に進行, 起立, 歩行不能と なる。

入院時所見：項頸部痛が強く頸椎の伸展制限があっ た. 右上肢の筋力は徒手筋力テストで 3 , 左上肢は 1 $\sim 2$, 下肢は $2 \sim 3$ 程度に低下し, 食事にも介助を要し た. JOA (日本整形外科学会) score は入院時 14 点満点 中 1 点であった.

検査所見：頸椎単純 X線像では破壊性脊椎関節症, 春 椎症変化，脊柱管狭窄などの異常を認めなかった.
ミエログラムでは，硬膜管が全頸椎にわたり椎間高位 と椎体高位とで同程度に圧迫され，全体的に細くなると いう，椎間板へルニアや頸椎症性脊髄症の圧迫像とは異 なった特異な所見を呈した (図 $1 \mathrm{a}$ ). 腰椎にも L4/5を 中心に狭窄所見を認めた。

CT ミエログラムでは $\mathrm{C} 2$ から C6 にかけて脊髄の扁 平化が認められ, 特に C3 から C5 にかけて高度であっ た. MRI では T 1 強調像で C $2 / 3$ から C $5 / 6$ にかけて, 頸髄は高度に圧迫されており，T2 強調像で同高位を中 心に後緃勒帯の肥厚が椎体後方の低信号域として認めら れた（図 $1 \mathrm{~b}, \mathrm{c}$ ).

\section{手術および術後経過}

1991 年 10 月 23 日, C1 椎弓切除, C2-7 棘突起縦割法 による脊柱管拡大術をハイドロキシアパタイトの棘突起 スペーサーを使用して行った。 手術時, アミロイド沈着 によると思われる棘間棘上勒帯の著明な肥厚を観察し た. 椎弓を縦割拡大すると, 肥厚した黄色䩚帯と硬膜が 広範に癒着しており,さらに硬膜外腔と硬膜の表面にア ミロイドの沈着を認めた.

術直後より四肢麻盘は急速に改善し， 6 週後の退院時 には, JOA score は 14 点満点中 9 点に改善して独步可 能となった。術後の CT と MRI にて, 脊䯣の除圧が確 認された（図 $1 \mathrm{~d}, \mathrm{e}$ ).

\section{病理組織所見}

手術時に採取された, 棘上勒帯, 黄色勒帯, 硬膜外腔 および硬膜表面の沈着物より, congo red 染色と抗 $\beta_{2}$ microglobulin 抗体による免疫組織染色陽性の多量のア ミロイド沈着が，証明された。

症例：黄色靱帯肥厚による腰部脊柱管狭窄症, 54 歳, 男性。

主訴：間欠性跛行.

現病歷：1991 年 8 月より腰痛出現. その後両下肢痛と 間欠性跛行による歩行障害が出現した。

既往歴：透析歴 17 年. 1989 年両側手根管開放術施行.

入院時所見：腰椎の後屈制限あり．2 分間の歩行によ り両下肢のしびれと脱力が増強する間欠性跛行を呈し た。両側 L5 髄節以下の表在知覚障害を認めた。両手指 に多発性の弾発指があり，屈曲拘縮を呈していた，両膝 関節はアミロイド関節症によると思われる疼痛, 腫脹と 屈曲拘縮があった。

検查所見：単純X線像では頸椎，腰椎とも明らかな異 常を認めなかった.

ミエログラムでは頸椎に軽度の, 腰椎には L3/4, L4/ 5 に高度の狭窄所見を認めた（図 2 a).

CT ミエログラムでは腰椎狭窄部にて黄色勒帯が著明 に肥厚し，硬膜管を圧迫していた（図 2 b ). 


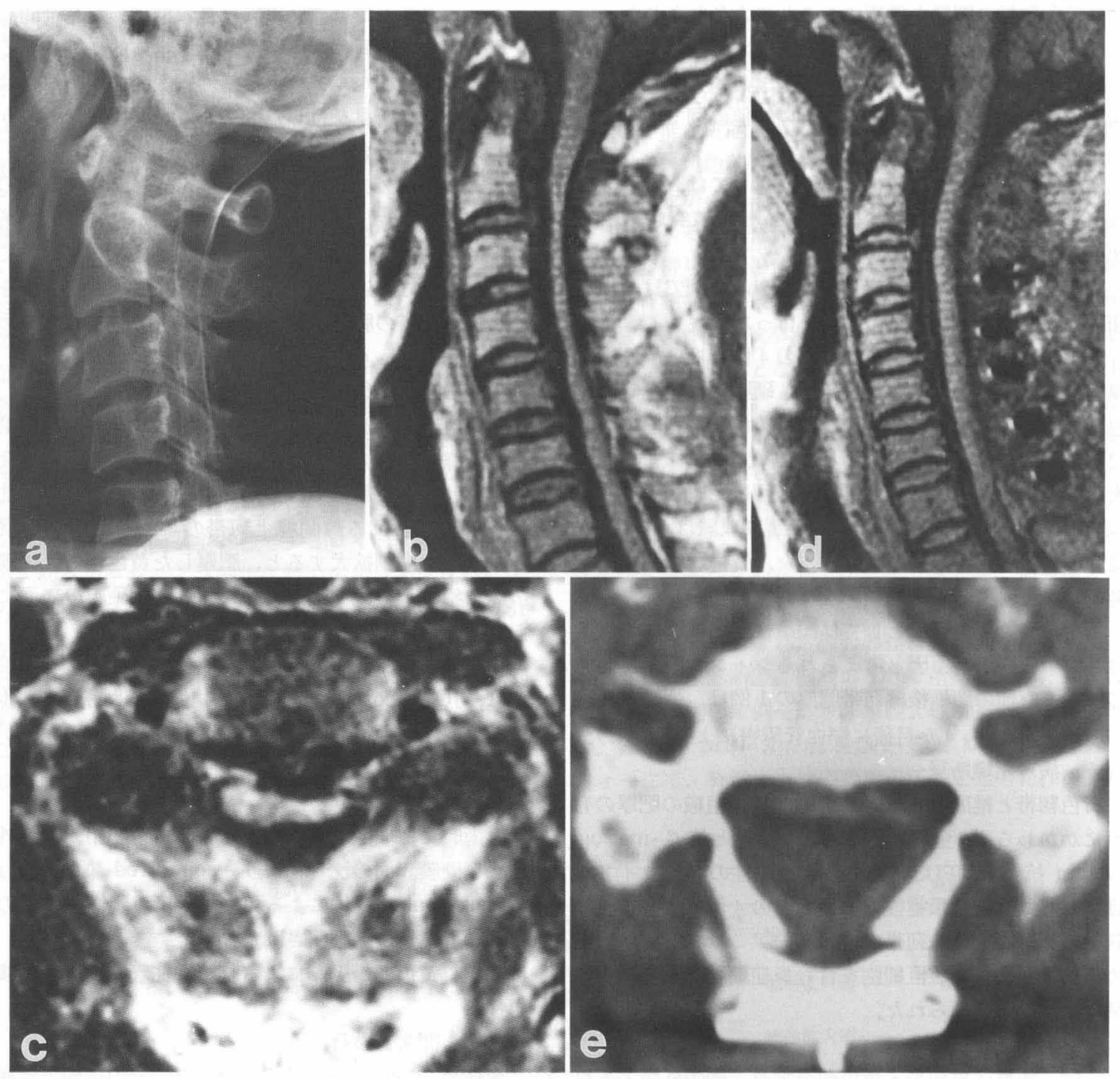

図 168 歳男性, 頸部脊髄症. a : ミエログラム. b : MRI (T1 強調), 脊髄の圧迫と椎体後方に連続し た低信号域を認める。 c : MRI (T1 強調水平断像) 後縦䩲帯肥厚と扁平化した脊䯣を認める. d : 術後 MRI（T1 強調）脊髄の圧迫は消失している. e : 術後 CT 像.

また頸椎でも $\mathrm{C} 2$ から $\mathrm{C} 5$ にかけて, 後縦靱带の肥厚 と軽度の脊髄扁平化を認めた。

治療経過：各種保存療法が無効であったため, 手術療 法を考慮した．画像診断上，頸椎にも異常を認めたが， 臨床所見より腰椎が責任高位と診断されたため, 腰椎の 除圧術を施行した. 1992 年, L4 椎弓切除を行い,さらに L3/4, L4/5 間の黄色勒帯を可及的に切除した．特に L4/ 5 間の黄色勒帯は厚さが最大 $13 \mathrm{~mm}$ と著明に肥厚し, 一部硬膜管と癒着していた (図 2 c). 手術後腰痛と間欠 性跛行は消失した。
病理組織所見：肥厚した黄色勒帯には, congo red 染 色と抗 $\beta_{2}$-microglobulin 抗体による免疫組織染色陽性 の多量のアミロイド沈着が，証明された．また炎症細胞 浸潤と線維性結合織の増殖がみられた（図 $2 \mathrm{~d}$ ).

考察

血液透析に関連する運動器の合併症としては, 手根管 症候群，骨囊腫，アミロイド関節症などが知られている が，手術療法を必要とするような脊椎疾患を合併する症 例も増加しつつある. その原因として, 透析患者の高齢 化と透析歷の長期化 ${ }^{1)}$ がすすみ，特に 20 年以上におよぶ 

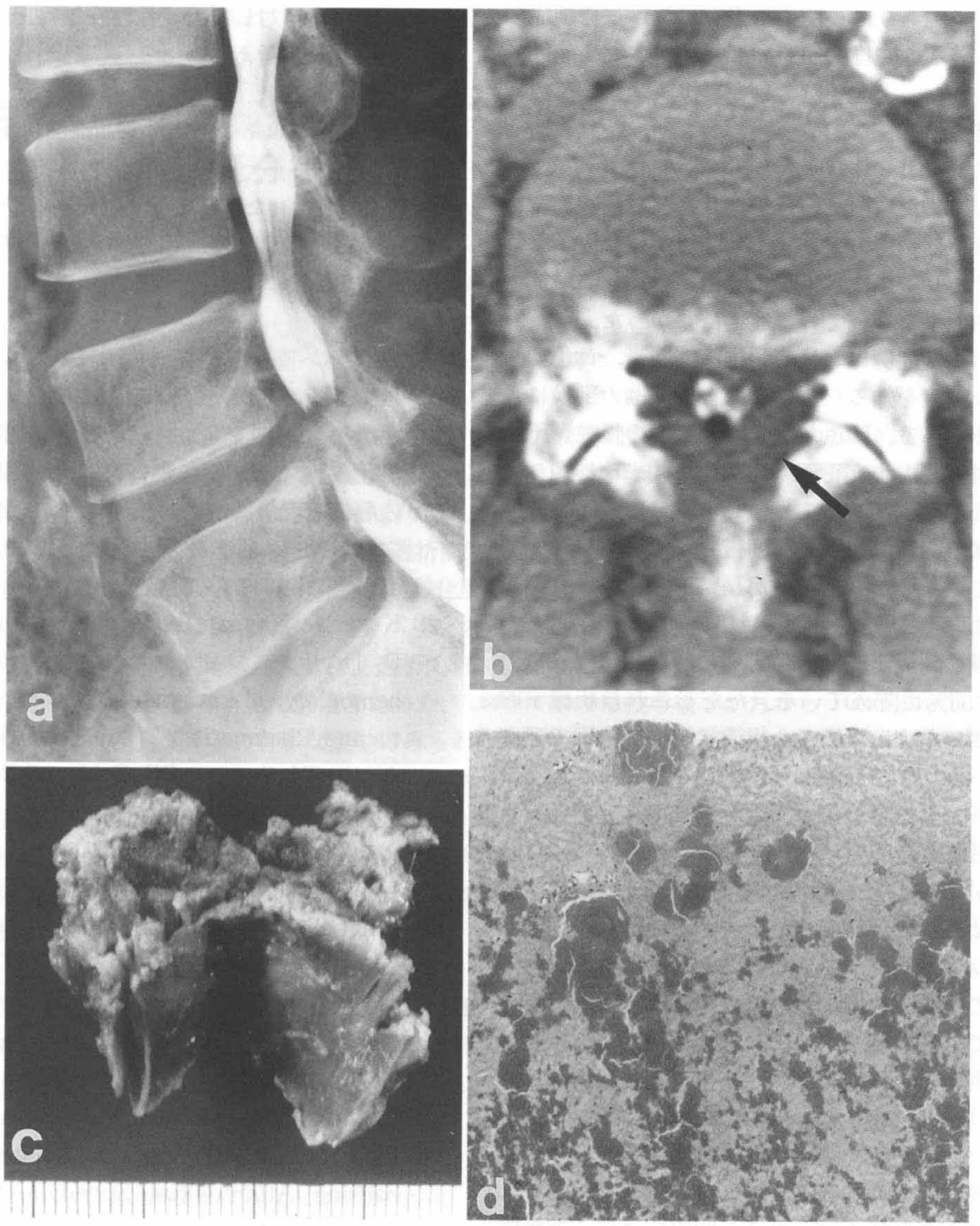

図 254 歳男性, 腰部脊柱管狭窄症。 a : ミエログラム。 b : CT ミエログラム, 黄色靱帯の肥厚を認め る (矢印)。c：著明に肥厚した黄色靯帯。 d : 黄色䩲帯内に沈着したアミロイド $(\times 200 \mathrm{HE})$.

例も増えてきたことに加え，手術前後の透析患者に対す る全身管理が，比較的安全に行えるようになったこと， 透析患者に特有な春椎疾患についての認識が高まってき たことなどがあげられる.

従来報告されてきた透析患者に特有な脊椎疾患として は, Kuntz $ら^{2)}$ による破壊性脊椎関節症, Allain ら ${ }^{3)}$ によ る硬膜外腔アミロイド沈着による頸髄症, 環軸椎周囲の アミロイド沈着や関節症に伴う春髄症 ${ }^{4,5)}$ などが知られ ている。このうち破壊性脊椎関節症については, 発症頻 度が高いことより手術例を含めて多数の報告があり, 透
析患者における代表的な春椎疾患と考えられている。し かし本症は諸家の報告でも頸部痛などの局所症状のみで 神経症状を呈する例は比較的少なく，二次的にすべりを 生じたり，脊柱管狭窄を合併する例を除き，手術療法を 必要とする例は少ないとされている ${ }^{6)}$. 自験例でもDSA が神経症状発現の直接の原因となっていたのは, 頸椎す べり症を生じた 1 例と腰椎すべり症を生じた 1 例のみで あった。

これに対し, アミロイド沈着に伴い頸椎後縦䩲帯, 黄 色勒帯肥厚を生じ，圧迫性脊髄症を呈した症例が，頸髄 
症手術 7 例中 4 例あり, 長期透析患者における脊髄症の 原因として, 破壊性脊椎関節症同様に注目すべき病態で あると考えられた。 上記 4 例では頸椎後緃勒帯, 黄色䩔 帯という鞄帯性の脊柱管構成要素とともに, 硬膜管周囲 の硬膜外腔にも Allain の症例と同様にアミロイド沈着 を認めている．また自験例の分析より腰部脊柱管狭窄に ついては, 黄色靱帯内のアミロイド沈着が狭窄因子とし て最も重要であり, 後縦靯帯や椎間板のアミロイド沈着 が主要な狭窄因子となっていた症例はなかった。

透析患者の脊髄症例におりる頸椎後縦勒帯, 黄色勒帯 肥厚の正確な頻度を知るためには，脊髄症例の剖検によ る検討が必要である. Honda ら ${ }^{7}$ は，95 例の慢性腎不全 剖検例の腰椎椎間板, 後縦勒帯内のアミロイドと $\beta_{2}-\mathrm{mi}-$ croglobulin の有無について調べている. 脊椎疾患の既 往, 臨床症状の有無, 肉眼的な勒帯肥厚の有無について は記載されていないが，透析歴が長いほど出現頻度が高 く, また高齢者ほど早期より出現し, 透析歴 15 年以上の 例では, 腰椎椎間板, 後縦靯帯ともに病理組織学的にア ミロイドを $100 \%$ に認めている．ただしこれは組織学的 所見での頻度であり自験例でも組織学的には全例でアミ ロイドが認められているが, 脊髄圧迫を生じ得るょうな 肉眼的な勒帯肥厚を全く認めない症例も存在している. 肉眼的な䩲帯肥厚の頻度についてはよく知られていない が, 我々の MRI による検討では ${ }^{8)}, 10$ 年以上の透析例に ついては脊髄症状の有無にかかわらず, 後縦勒帯肥厚と 黄色勒帯肥厚は各々 $47.6 \%, 23.8 \%$ と高率に認められて いる. 従って長期透析例に扔いては病理組織学的または 画像診断上の, 春椎勒帯内のアミロイド沈着および肥厚 は, 無症候例においても高率に存在すると推察される.

透析アミロイドーシスによる勒帯肥厚の診断では通常 DSA のような椎間板変性を伴わないこと, 頸椎症性脊髄 症のような典型的な脊髄症状を呈さない例も多いこと, 手根管症候群や多発性のアミロイド関節症に伴う運動障 害を高率に合併しやすいことより，本症の存在を見逃さ ないよう注意する必要がある. 治療については頸椎では 脊柱管拡大術, 腰椎では椎弓および黄色勒帯切除により 一般の非透析例と同様に良好な手術成績が短期的には期 待できる.ただしアミロイド沈着は進行性と考え, 通常 の変性疾患より余裕を持った除圧を心がけるべきであろ う.

\section{結論}

1. 15 年以上の長期透析例では, アミロイド沈着によ る後縦勒帯・黄色勒帯肥厚が頸部脊髄症や腰部脊柱管狭 窄症の原因として重要である. 本疾患では単純X線所見 は通常正常であり, 破壊性脊椎関節症とは異なった疾患 群として注目すべきである。
2. 本疾患に対しても変性性脊椎疾患と同様に後方除 圧手術が有効と考える.

本論文の要旨は第 38 回日本透析療法学会総会において発 表した.

謝辞：御協力いただいた，大坪公子（三軒茶屋病院腎臟内 科), 山下賀正 (代々木山下医院), 須田昭夫 (須田クリニッ ク）の各先生方に深謝いたします。

\section{文献}

1）秋葉 隆, 北岡建樹, 久保和雄, 佐々木隆一郎, 澤 西謙次, 山上征二, 山崎親雄, 和田孝雄, 飯田喜俊, 尾辻義人, 小野俊彦, 川口良人, 今 忠正, 斉藤 明, 佐藤 威, 篠田 晤, 嶋田俊恒, 関野 宏, 中川成 之輔, 沼田 明, 平沢由平, 前田憲志：透析患者の 高齢化に関する検討. 透析会誌 $25 ： 445-450,1992$

2) Kuntz D, Naveau B, Bardin T, Drueke T, Treves R, Dryll A : Destructive Spondylarthropathy in hemodialyzed Patients-A new syndrome. Arthritis and Rheumatism $27: 369-375,1984$

3) Allain TJ, Stevens PE, Bridges LR, Phillip ME : Dialysis myelopathy: quadriparesis due to extradural amyloidosis of $\beta_{2}$ microglobulin origin. British Medical Journal 296 : 752-753, 1988

4) Rousselin B, Heienon O, Zingraff J, Delons S, Drueke T, Bardin T, Moreau JF : Pseudotumor of the craniocervical junction during long-term hemodialysis. Arthritis Rheum $33: 1567-1573$, 1990

5) Kröner G, Stäbler A, Seidere M, Moran JE, Gurland $\mathrm{HJ}: \beta_{2}$ Microglobulin-Related Amyloidosis causing Atlantoaxial Spondylarthropathy with Spinal-Cord Compression in Haemodialysis Patients : Detection by MRI. Nephrol Dial Transplant 2(Suppl) : 91-95, 1991

6）内藤正俊：血液透析患者の骨・関節合併症一透析ア ミロイド症を起因とする疾患を中心に一. 日整会誌 $66: 1084-1090,1992$

7) Honda K, Hara M, Ogura $Y$, Nihei H, Mimura $\mathrm{N}: \beta_{2}$-Microglobulin Amyloidosis in Hemodialysis Patients An Autopsy Study of Intervertevral Disks and Posterior Longitudinal Ligaments. Acta Pathol Jpn 40 : 820-826, 1990

8）佐野浩志, 久野木順一, 奥津一郎, 蓮江光男 : 長期 血液透析患者における頸椎後縦勒帯, 黄色勒帯肥厚 症の検討. 日本脊椎外科学会 $4: 231,1993$ 